\title{
Proteiniborus ethanoligenes gen. nov., sp. nov., an anaerobic protein-utilizing bacterium
}

\author{
Correspondence \\ Xiuzhu Dong \\ dongxz@sun.im.ac.cn
}

\author{
Lili Niu, ${ }^{1,2}$ Lei Song ${ }^{1,2}$ and Xiuzhu Dong ${ }^{1}$ \\ ${ }^{1}$ State Key Laboratory of Microbial Resources, Institute of Microbiology, Chinese Academy of \\ Sciences, Beijing 100101, PR China \\ ${ }^{2}$ Graduate School, Chinese Academy of Sciences, Beijing 100049, PR China
}

\begin{abstract}
A novel anaerobic, mesophilic, protein-utilizing bacterial strain, $\mathrm{GW}^{\top}$, was isolated from the mesophilic hydrogen-producing granular sludge used to treat food industry wastewater. The strain was a Gram-positive, non-spore-forming and non-motile rod. Growth of the strain was observed at $20-48{ }^{\circ} \mathrm{C}$ and at $\mathrm{pH}$ 6.4-10.0. The strain used yeast extract and peptone as carbon and energy sources. Weak growth was also observed with tryptone and Casamino acids as carbon and energy sources. The strain used none of the tested carbohydrates, alcohols or fatty acids. The fermentation products in peptone-yeast broth included ethanol, acetic acid, hydrogen and carbon dioxide. Gelatin was not hydrolysed. Nitrate was reduced. Indole was produced. $\mathrm{NH}_{3}$ and $\mathrm{H}_{2} \mathrm{~S}$ were not produced. The DNA G+C content of strain $\mathrm{GW}^{\top}$ was $38.0 \mathrm{~mol} \%$. The predominant cellular fatty acids were the saturated fatty acids $\mathrm{C}_{14: 0}(15.58 \%), \mathrm{C}_{16: 0}(25.40 \%)$ and $\mathrm{C}_{18: 0}(12.03 \%)$. Phylogenetic analysis based on 16S rRNA gene sequence similarity revealed that strain $\mathrm{GW}^{\top}$ represented a new branch within cluster XII of the Clostridium subphylum, with <89.6\% 16S rRNA gene sequence similarities to all described species. On the basis of polyphasic evidence from this study, strain $\mathrm{GW}^{\top}$ represents a new genus and novel species, for which the name Proteiniborus ethanoligenes gen. nov., sp. nov. is proposed. The type strain is $\mathrm{GW}^{\top}\left(=\mathrm{CGMCC} 1.5055^{\top}=\mathrm{JCM} 14574^{\top}\right)$.
\end{abstract}

Hydrogen is a clean and renewable energy source, and bioproduction of hydrogen by micro-organisms falls into two main categories: photosynthetic biohydrogenesis and fermentative biohydrogenesis by anaerobic bacteria. One of the advantages of the fermentative biohydrogenesis process is the possibility of using organic wastes for bio-energy production through anaerobic degradation. Anaerobic degradation is a widely applied and economically attractive technology used in the treatment of various organic wastes (Lettinga, 1995). Currently most investigations concerning anaerobic degradation of organic materials have focused on the metabolism of carbohydrates, especially in the fermentative biohydrogenesis process. However, many industrial and agricultural wastes also contain a considerable amount of proteinaceous materials and fat. Although part of this can be digested by some saccharide users, the protein-specific degraders are needed to remove proteinaceous materials efficiently from the wastewater.

In recent years, a few protein-specific anaerobic degraders, such as Clostridium thiosulfatireducens (Hernández-Eugenio

The GenBank/EMBL/DDBJ accession number for the 16S rRNA gene sequence of Proteiniborus ethanoligenes $\mathrm{GW}^{\top}$ is EF116488.

An electron micrograph of an ultrathin section of strain $\mathrm{GW}^{\top}$ is available with the online version of this paper. et al., 2002), 'Clostridium tunisiense' (Thabet et al., 2004) and Proteiniphilum acetatigenes (Chen \& Dong, 2005), have been isolated from upflow anaerobic sludge blanket (UASB) reactor sludge. They were all proteolytic, chemo-organotrophic anaerobic bacteria characterized by using only proteinaceous compounds, but not any tested carbohydrates, as a carbon and energy source. During a study on the microbial composition of a fermentative hydrogen-producing reactor, several hydrogen-producing anaerobic bacterial strains were isolated with a rich medium (glucose-peptone-yeast extract), among which was a proteinaceous compound-specific strain. Phylogenetically the strain was affiliated to the phylum of low G + C Grampositive bacteria but was distantly related to all the existing species. Hence a novel mesophilic, protein-utilizing, hydrogen-producing anaerobe is described in this paper.

A pre-reduced PY medium (Holdeman et al., 1977) was used for isolation and routine cultivation. Granular sludge from a laboratory-scale UASB reactor for treating food industry wastewater and producing hydrogen was used as inoculum. Granules were crushed with a mortar in an anaerobic glove box (Forma scientific 1209) and then inoculated into the pre-reduced PY broth under $100 \% \mathrm{~N}_{2}$. After the enrichments were incubated at $37{ }^{\circ} \mathrm{C}$ for $24 \mathrm{~h}$, the Hungate roll-tube technique (Hungate, 1969) was 
performed. Single colonies in the roll-tube were picked and transferred to the same broth and incubated at $37{ }^{\circ} \mathrm{C}$ for 2 days. The roll-tube procedure was repeated several times until a pure culture of strain $\mathrm{GW}^{\mathrm{T}}$ was obtained. The purity of the culture was examined under a light microscope.

Substrate utilization studies were performed in a basal medium containing different substrates as follows: Casamino acids, peptone, yeast extract and tryptone $(0.2 \%$, final concentration); sugars, fatty acids $(20 \mathrm{mM}$, final concentration) and amino acids $(0.2 \%$, final concentration). The basal medium contained $\left(\mathrm{l}^{-1}\right): 1 \mathrm{~g} \mathrm{NH}_{4} \mathrm{Cl}$, $\begin{array}{llllll}0.3 \mathrm{~g} \quad \mathrm{KH}_{2} \mathrm{PO}_{4}, \quad 0.3 \mathrm{~g} \quad \mathrm{~K}_{2} \mathrm{HPO}_{4}, \quad 0.6 \mathrm{~g} & \mathrm{NaCl}, & 0.1 \mathrm{~g}\end{array}$ $\mathrm{CaCl}_{2} \cdot 2 \mathrm{H}_{2} \mathrm{O}, 0.1 \mathrm{~g} \mathrm{MgCl}_{2} \cdot 6 \mathrm{H}_{2} \mathrm{O}$ and $1 \mathrm{mg}$ resazurin. The $\mathrm{pH}$ was adjusted to 7.5 with $1 \mathrm{M} \mathrm{NaOH}$.

Cell morphology was examined under a light (Olympus $\mathrm{BH}-2$ ) and electron (Hitachi H-600A) microscope. For electron microscopy studies, bacterial cells grown in PY at $37^{\circ} \mathrm{C}$ for $24 \mathrm{~h}$ were negatively stained with uranyl acetate. For ultrathin section examination of the cell wall, bacterial cells were fixed with osmic acid and embedded in araldite; the samples were then sliced and stained with lead citrate (Reynolds, 1963).

The generation time of strain $\mathrm{GW}^{\mathrm{T}}$ was determined by monitoring the $\mathrm{OD}_{600}$ of the PY culture at $37^{\circ} \mathrm{C}$ at $1 \mathrm{~h}$ intervals up to $48 \mathrm{~h}$. The temperature profile was determined in PY using a water bath with temperature controller between temperatures of 15 to $55{ }^{\circ} \mathrm{C}$ at $1{ }^{\circ} \mathrm{C}$ intervals. The $\mathrm{pH}$ range for growth was determined for the culture in $\mathrm{PY}$ broth at various $\mathrm{pH}$ values adjusted with $\mathrm{HCl}$ or $\mathrm{NaOH}\left(1 \mathrm{~mol} \mathrm{l}^{-1}\right)$. Growth was determined by measuring the $\mathrm{OD}_{600}$ of cultures at 1,3 and 7 days. Biochemical traits were determined using conventional methods. All tests were performed in duplicate. The fermentation products, short-chain fatty acids, alcohols and gases were measured using a gas chromatograph (GC14B Shimadzu) as described previously (Chen \& Dong, 2004). The diagnostic isomers of diaminopimelic acid and amino acids in the cell wall were determined with established TLC procedures (Lechevalier \& Lechevalier, 1980). Cellular fatty acids were extracted, methylated and analysed using the standard MIDI (Microbial Identification) system (Miller, 1982; Sasser, 1990).

Genomic DNA was extracted and purified using the method of Marmur (1961). The G+C content of the DNA was determined by the thermal denaturation method (Marmur \& Doty, 1962) using a DU800 spectrophotometer (Beckman) with Escherichia coli K-12 as the reference. The $16 \mathrm{~S}$ rRNA gene was amplified and sequenced according to Chen \& Dong (2004). The sequencing was performed by Sangon Biological Engineering Technology Service, Shanghai, China, using ABI PRISM Big Dye Terminator cycle sequencing ready reaction kits (Perkin Elmer) and an ABI PRISM 377XL DNA sequencer. The 16S rRNA gene sequence of strain $\mathrm{GW}^{\mathrm{T}}$ was submitted to GenBank and EMBL to search for similar sequences using the BLAST algorithm (Altschul et al., 1990). Sequences with higher similarities were retrieved from the database and aligned and similarity analysis was performed using the CLUSTAL_X program (Thompson et al., 1997). Phylogenetic trees were constructed using the neighbour-joining, maximum-likelihood and maximum-parsimony methods implemented in the program MEGA3 (Kumar et al., 2004). The resultant tree topologies were evaluated by bootstrap analysis (Felsenstein, 1985) based on 1000 resamplings.

Cells of strain $\mathrm{GW}^{\mathrm{T}}$ were non-motile short rods (supplementary Fig. S1 in IJSEM Online), $0.5-0.6 \mu \mathrm{m} \times 1.4-$ $3.8 \mu \mathrm{m}$, and arranged singly or in clumps. The cells stained Gram-negative in all the growth phases; however, a Grampositive bacterial cell wall ultrastructure was revealed by electron microscopy (Fig. 1). Spores were never observed. Colonies on PY agar were white, smooth, circular and entire and slightly convex and reached $0.5 \mathrm{~mm}$ after cultivation at $37^{\circ} \mathrm{C}$ for $72 \mathrm{~h}$.

Strain $\mathrm{GW}^{\mathrm{T}}$ grew strictly anaerobically and growth occurred from 20 to $48{ }^{\circ} \mathrm{C}$ and at $\mathrm{pH}$ 6.4-10.0, with optimum growth at $37^{\circ} \mathrm{C}$ and at approximately $\mathrm{pH} 8.5-$ 8.8. The strain could grow in the presence of $0-2 \%(\mathrm{w} / \mathrm{v})$ $\mathrm{NaCl}$. The doubling time of strain $\mathrm{GW}^{\mathrm{T}}$ was $3.3 \mathrm{~h}$ when growing on PY at $37{ }^{\circ} \mathrm{C}$. The strain used proteinaceous compounds exclusively, and did not use any of the tested carbohydrates, alcohols or fatty acids. Yeast extract and peptone could be used as carbon and energy sources. Weak growth was also observed with tryptone and Casamino acids, but the strain did not use any of the single amino acids. When growing in $0.4 \%$ yeast extract and $0.2 \%$ peptone medium, $15 \mathrm{mM}$ ethanol, $10 \mathrm{mM}$ hydrogen, $6 \mathrm{mM}$ acetate and a trace amount of propionate were produced. Strain $\mathrm{GW}^{\mathrm{T}}$ hydrolysed casein, but not gelatin or DNA, and did not curdle milk. Indole was produced from yeast extract and peptone; however, $\mathrm{NH}_{3}$ was not produced. Nitrate could be utilized as electron acceptor. No $\mathrm{H}_{2} \mathrm{~S}$ was produced from peptone or thiosulfate.

The cell wall hydrolysate of strain $\mathrm{GW}^{\mathrm{T}}$ was rich in L-lysine, but no diaminopimelic acids were detected. The cellular fatty acids of strain $\mathrm{GW}^{\mathrm{T}}$ were characterized mainly by saturated fatty acids, predominantly $\mathrm{C}_{14: 0}(15.58 \%), \mathrm{C}_{16: 0}$ $(25.40 \%)$ and $\mathrm{C}_{18: 0} \quad(12.03 \%) ; \mathrm{C}_{18: 1} \omega 9 c \quad(11.20 \%)$, $\mathrm{C}_{16: 1} \omega 7 c(6.18 \%)$, isoC $\mathrm{C}_{17: 1} \mathrm{I}(9.49 \%)$ and isoC $_{15: 0}$ $(4.30 \%)$ were also relatively abundant.

The genomic DNA G+C content of strain $\mathrm{GW}^{\mathrm{T}}$ was determined as $38.0 \mathrm{~mol} \%$.

To ascertain the phylogenetic position of the novel strain, the complete $16 \mathrm{~S}$ rRNA gene sequence $(1523 \mathrm{bp})$ of strain $\mathrm{GW}^{\mathrm{T}}$ was compared with the most similar sequences and those of the representatives of the 'Clostridia' retrieved from GenBank. On the basis of a consensus $1367 \mathrm{bp}$ of the $16 \mathrm{~S}$ rRNA gene sequence, a phylogenetic tree rooted with Peptostreptococcus hydrogenalis GIFU $7662^{\mathrm{T}}$ was constructed. Phylogenetic analysis showed that strain $\mathrm{GW}^{\mathrm{T}}$ was affiliated to the low G+C Gram-positive bacteria phylum, and belonged to cluster XII of the 'Clostridia' 


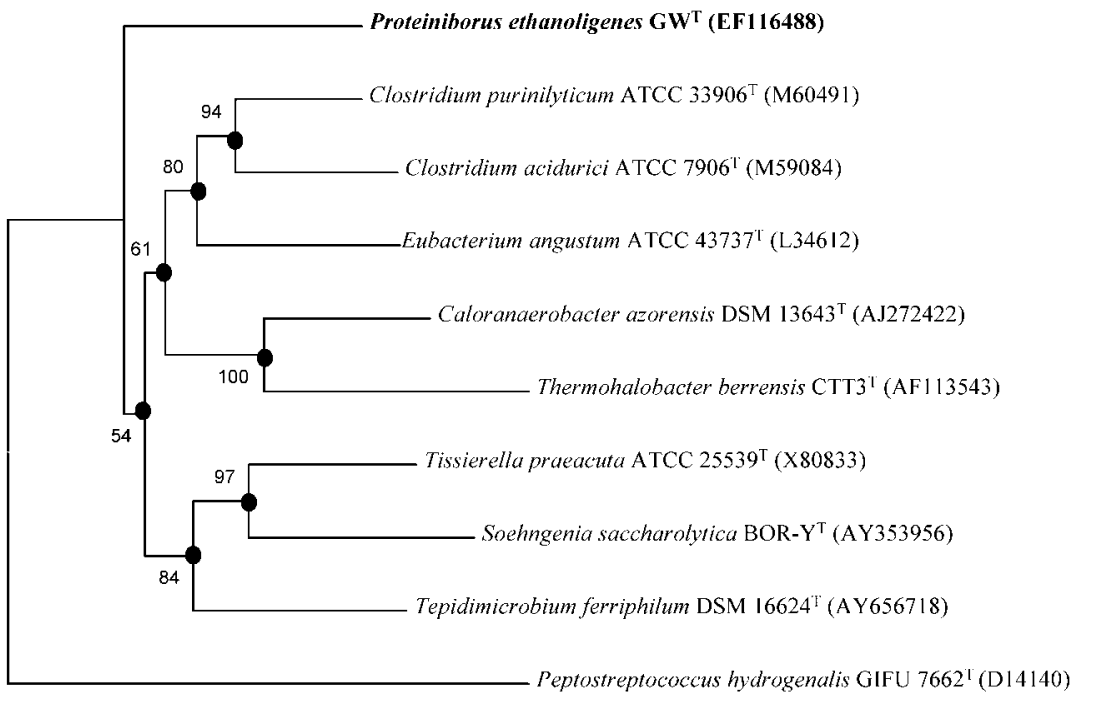

$\vdash$
Fig. 1. Phylogenetic dendrogram of $16 \mathrm{~S}$ rRNA gene sequences indicating the position of strain $\mathrm{GW}^{\top}$ among the bacterial members in cluster XII of the 'Clostridia'. The tree rooted with Peptostreptococcus hydrogenalis was constructed using the neighbour-joining method. Solid circles indicate that the corresponding nodes (groups) are also recovered in UPGMA and minimum evolution methods. Numbers at nodes represent levels of bootstrap support (\%) based on a neighbourjoining analysis of 1000 resampled datasets. GenBank accession numbers of $16 \mathrm{~S}$ rRNA sequences are given in parentheses. Bar, $2 \%$ sequence divergence.
(Collins et al., 1994). The closest relatives were Clostridium purinilyticum, Clostridium acidurici and Eubacterium angustum, with sequence similarity levels of $89.7,88.9$ and $88.8 \%$, respectively. The similarity levels of the $16 \mathrm{~S}$ rRNA gene sequence with that of other members in phylogenetic cluster XII ranged between 86 and $88 \%$. Trees constructed by neighbour-joining, UPGMA and minimum evolution showed the same topology. The 16S rRNA sequence of strain $\mathrm{GW}^{\mathrm{T}}$ is not closely related to that of previously described taxa and represents a novel genus.
Strain $\mathrm{GW}^{\mathrm{T}}$ also showed distinct phenotypic features distinguishing it from representative members in the same cluster (Table 1). Clostridium purinilyticum, Clostridium acidurici and Eubacterium angustum grew exclusively on purines, such as uric acid and adenine (Dürre et al., 1981; Cato et al., 1986; Beuscher \& Andreesen, 1984), however strain $\mathrm{GW}^{\mathrm{T}}$ could not use these substances at all. Also, the three species were not able to use proteinaceous materials as sole carbon and energy sources. Moreover, strain $\mathrm{GW}^{\mathrm{T}}$ was also different from the species Caloranaerobacter

Table 1. Characteristics differentiating strain $\mathrm{GW}^{\top}$ from its phylogenetic relatives

Species: 1, Proteiniborus ethanoligenes JCM $14574^{\mathrm{T}}$; 2, Clostridium purinilyticum ATCC $33906^{\mathrm{T}}$ (Dürre et al., 1981); 3, Eubacterium angustum ATCC $43737^{\mathrm{T}}$ (Beuscher \& Andreesen, 1984); 4, Caloranaerobacter azorensis DSM $13643^{\mathrm{T}}$ (Wery et al., 2001); 5, Thermohalobacter berrensis $\mathrm{CTT}^{\mathrm{T}}$ (Cayol et al., 2000). Symbols: +, positive; - , negative; NR, not reported.

\begin{tabular}{|c|c|c|c|c|c|}
\hline Characteristic & 1 & 2 & 3 & 4 & 5 \\
\hline Inhabiting niche & UASB sludge & Farm soil & Sewage sludge & Deep-sea hydrothermal vent & Solar saltern \\
\hline Gram type & + & + & + & - & - \\
\hline Spore formation & - & + & - & - & - \\
\hline Motility & - & + & - & + & + \\
\hline Optimum temp. $\left({ }^{\circ} \mathrm{C}\right)$ & 37 & 36 & 37 & 65 & 65 \\
\hline Optimum $\mathrm{pH}$ & $8.5-8.8$ & $7.3-7.8$ & $8.0-8.2$ & 7.0 & 7.0 \\
\hline Glucose fermentation & - & - & - & + & + \\
\hline Major products from $\mathrm{PYG}^{\star}$ & $\mathrm{A} 2 \mathrm{p}$ & - & - & Aiv & A2 \\
\hline Peptone used as carbon source & + & - & - & - & - \\
\hline Purine utilized & - & + & + & - & - \\
\hline Hydrogen produced & + & + & + & - & + \\
\hline Hydrolysis of gelatin & - & - & + & NR & - \\
\hline Nitrate reduced & + & - & - & - & - \\
\hline $\mathrm{G}+\mathrm{C}$ content $(\mathrm{mol} \%)$ & 38.0 & 29 & 40.3 & 27 & 33 \\
\hline
\end{tabular}

${ }^{\star}$ Products: a, acetic acid; p, propionic acid; iv, isovaleric acid; 2, ethanol. Upper-case and lower-case letters indicate major and minor fermentation products, respectively. 
azorensis and Thermohalobacter berrensis in the same phylogenetic branch in the optimal growth temperature and substrate range: while strain $\mathrm{GW}^{\mathrm{T}}$ is mesophilic and a protein-consumer, the other two species grow optimally at $65{ }^{\circ} \mathrm{C}$ and are sugar-consumers (Wery et al., 2001; Cayol et al., 2000).

On the basis of the physiological properties and the phylogenetic analyses, strain $\mathrm{GW}^{\mathrm{T}}$ is proposed as a novel genus and novel species, Proteiniborus ethanoligenes gen. nov., sp. nov., affiliated with the low $\mathrm{G}+\mathrm{C}$ Gram-positive bacteria phylum.

\section{Description of Proteiniborus gen. nov.}

Proteiniborus (Pro.tei.ni'bo.rus. N.L. n. proteinum protein; Gr. adj. boros gluttonous; N.L. masc. n. Proteiniborus protein-consumer).

Gram-positive, non-motile, non-spore-forming rod. Anaerobic and mesophilic. Cell wall peptidoglycan contains abundant L-lysine but not diaminopimelic acids. Cellular fatty acids consist mainly of saturated fatty acids, predominantly $\mathrm{C}_{14: 0}, \mathrm{C}_{16: 0}$ and $\mathrm{C}_{18: 0}$. Chemo-organotrophic. Yeast extract and peptone can be used as energy sources. The fermentation products from PY include ethanol, acetic acid, hydrogen and carbon dioxide. Nitrate but not thiosulfate is reduced. The G $+\mathrm{C}$ content of the genomic DNA of the known strain is $38.0 \mathrm{~mol} \%$. The type species of the genus is Proteiniborus ethanoligenes, a member of cluster XII of the 'Clostridia'.

\section{Description of Proteiniborus ethanoligenes sp. nov.}

Proteiniborus ethanoligenes (e.tha.no.li'ge.nes. N.L. n. ethanol-is ethanol; Gr. v. gennao produce; N.L. part. adj. ethanoligenes ethanol-producing).

Morphology and general characteristics are as described for the genus. Cells are $0.5-0.6 \mu \mathrm{m}$ wide and $1.4-3.8 \mu \mathrm{m}$ long. Colonies on PY agar are white, smooth, circular and entire and slightly convex and reach $0.5 \mathrm{~mm}$ after cultivation at $37{ }^{\circ} \mathrm{C}$ for $72 \mathrm{~h}$. Growth occurs between 20 and $48{ }^{\circ} \mathrm{C}$ (optimum $37^{\circ} \mathrm{C}$ ) and at pH 6.4-10.0 (optimum 8.5-8.8). Besides yeast extract and peptone, weak growth is also observed on tryptone and Casamino acids. Ethanol, acetic acid and hydrogen are the main products from yeast extract and peptone, and a trace amount of propionic acid is also produced. The following substrates are not used: Lserine, L-threonine, L-alanine, L-histidine, L-leucine, Llysine, L-methionine, L-phenylalanine, L-valine, L-glutamine, L-arginine, L-tyrosine, tryptophan, L-isoleucine, Lproline, aspartate, L-cysteine, L-arabinose, cellobiose, aesculin, D-fructose, D-galactose, D-glucose, glycogen, inulin, D-lactose, maltose, mannose, melibiose, raffinose, rhamnose, ribose, sucrose, salicin, sorbose, starch, trehalose, Dxylose, adonitol, amygdalin, dulcitol, erythritol, inositol, mannitol, sorbitol, ribitol, methanol, ethanol, 1-propanol, citrate, fumarate, malate, succinate, malonate, hippurate, sodium gluconate, butane diacid, $\beta$-hydroxybutyric acid, phenylacetic acid, cellulose and xylan. Milk is not curdled. Indole is produced. $\mathrm{No} \mathrm{NH}_{3}$ is produced from yeast extract or peptone. Methyl red and Voges-Proskauer tests are negative. Casein is degraded and nitrate is reduced. Gelatin and DNA are not hydrolysed.

The type strain is $\mathrm{GW}^{\mathrm{T}}$ (=CGMCC $1.5055^{\mathrm{T}}=\mathrm{JCM}$ $14574^{\mathrm{T}}$ ), isolated from granular sludge from a laboratoryscale UASB hydrogen-producing reactor used to treat food industry wastewater.

\section{Acknowledgements}

This study was supported by the National Basic Research Program of China (2004 CB719602).

\section{References}

Altschul, S. F., Gish, W., Miller, W., Myers, E. W. \& Lipman, D. J. (1990). Basic local alignment search tool. J Mol Biol 215, 403-410.

Beuscher, H. U. \& Andreesen, J. R. (1984). Eubacterium angustum sp. nov., a Gram-positive anaerobic, non-sporeforming, obligate purine fermenting organism. Arch Microbiol 140, 2-8.

Cato, E. P., George, W. L. \& Finegold, S. M. (1986). Genus Clostridium Prazmowski 1880, 23 ${ }^{\mathrm{AL}}$. In Bergey's Manual of Systematic Bacteriology, vol. 2, pp. 1141-1200. Edited by P. H. A. Sneath, N. S. Mair, M. E. Sharpe \& J. G. Holt. Baltimore: Williams \& Wilkins.

Cayol, J.-L., Ducerf, S., Patel, B. K. C., Garcia, J.-L., Thomas, P. \& Ollivier, B. (2000). Thermohalobacter berrensis gen. nov., sp. nov., a thermophilic, strictly halophilic bacterium from a solar saltern. Int $J$ Syst Evol Microbiol 50, 559-564.

Chen, S. \& Dong, X. (2004). Acetanaerobacterium elongatum gen. nov., sp. nov., from paper mill wastewater. Int J Syst Evol Microbiol 54, 2257-2262.

Chen, S. \& Dong, X. (2005). Proteiniphilum acetatigenes gen. nov., sp. nov., from a UASB reactor treating brewery wastewater. Int $J$ Syst Evol Microbiol 55, 2257-2261.

Collins, M. D., Lawson, P. A., Willems, A., Cordoba, J. J., FernandezGarayzabal, J., Garcia, P., Cai, J., Hippe, H. \& Farrow, J. A. E. (1994). The phylogeny of the genus Clostridium: proposal of five new genera and eleven new species combinations. Int J Syst Bacteriol 44, 812-826.

Dürre, P., Andersch, W. \& Andreesen, J. R. (1981). Isolation and characterization of an adenine-utilizing, anaerobic sporeformer, Clostridium purinolyticum sp. nov. Int J Syst Bacteriol 31, 184-194.

Felsenstein, J. (1985). Confidence limits on phylogenies: an approach using the bootstrap. Evolution 39, 783-791.

Hernández-Eugenio, G., Fardeau, M.-L., Cayol, J.-L., Patel, B. K. C., Thomas, P., Macarie, H., Garcia, J.-L. \& Ollivier, B. (2002). Clostridium thiosulfatireducens sp. nov., a proteolytic, thiosulfate- and sulfurreducing bacterium isolated from an upflow anaerobic sludge blanket (UASB) reactor. Int J Syst Evol Microbiol 52, 1461-1468.

Holdeman, L. V., Cato, E. P. \& Moore, W. E. C. (1977). Anaerobe Laboratory Manual, 4th edn. Blacksburg, VA: Virginia Polytechnic Institute and State University.

Hungate, R. E. (1969). A roll tube method for cultivation of strict anaerobes. Methods Microbiol 3B, 117-132.

Kumar, S., Tamura, K. \& Nei, M. (2004). MEGA 3: integrated software for molecular evolutionary genetics analysis and sequence alignment. Brief Bioinform 5, 150-163. 
Lechevalier, M. P. \& Lechevalier, H. A. (1980). The chemotaxonomy of actinomyces. In Actinomycete Taxonomy, Special Publication 6, pp. 227-291. Arlington, VA:Society for Industrial Microbiology.

Lettinga, G. (1995). Anaerobic digestion and wastewater treatment system. Antonie Van Leeuwenhoek 67, 3-28.

Marmur, J. (1961). A procedure for the isolation of deoxyribonucleic acid from microorganisms. J Mol Biol 3, 208-218.

Marmur, J. \& Doty, P. (1962). Determination of the base composition of deoxyribonucleic acid from its thermal denaturation temperature. $J$ Mol Biol 5, 109-118.

Miller, L. T. (1982). Single derivation method for routine analysis of bacterial whole-cell fatty acid-methyl esters, including hydroxy acids. J Clin Microbiol 16, 584-586.

Reynolds, E. S. (1963). The use of lead citrate at high $\mathrm{pH}$ as an electron-opaque stain in electron microscopy. J Cell Biol 17, 208-212.
Sasser, M. (1990). Identification of bacteria by gas chromatography of cellular fatty acids. MIDI Technical Note 101. Newark, DE: MIDI.

Thabet, O. B. D., Fardeau, M.-L., Joulian, C., Thomas, P., Hamdi, M., Garcia, J.-L. \& Ollivier, B. (2004). Clostridium tunisiense sp. nov., a new proteolytic, sulfur-reducing bacterium isolated from an olive mill wastewater contaminated by phosphogypse. Anaerobe 10, 185-190.

Thompson, J. D., Gibson, T. J., Plewniak, F., Jeanmougin, F. \& Higgins, D. G. (1997). The CLUSTAL_X windows interface: flexible strategies for multiple sequence alignment aided by quality analysis tools. Nucleic Acids Res 25, 4876-4882.

Wery, N., Moricet, J.-M., Cueff, V., Jean, J., Pignet, P., Lesongeur, F., Cambon-Bonavita, M.-A. \& Barbier, G. (2001). Caloranaerobacter azorensis gen. nov., sp. nov., an anaerobic thermophilic bacterium isolated from a deep-sea hydrothermal vent. Int J Syst Evol Microbiol 51, 1789-1796. 